\title{
Struktur Sebaran Ruang Terbuka Hijau di Kota Makassar
}

\author{
* Aris Sakar Dollah ${ }^{1}$, Rasmawarni ${ }^{1}$ \\ ${ }^{1}$ Prodi Arsitektur, Fakultas Teknik, Universitas Muhammadiyah Makassar, Indonesia \\ Alamat Email: arisdol@unismuh.ac.id \\ *Alamat korespondensi, Masuk: 20 Feb. 2019, Direvisi: 07 Mar. 2019, Diterima: 09 Mar. 2019
}

\begin{abstract}
ABSTRAK: Penelitian ini bertujuan untuk menganalisis ruang terbuka hijau di Kota Makassar dari aspek luasan dan struktur penyebarannya. Alat ukur yang dipergunakan untuk melihat ketersediaan dan penyebaran adalah Permen PU Nomor 5 Tahun 2008. Penelitian ini dilakukan dengan metode survei dengan analisis deskriptif. Teknik analisis mempergunakan tabel persentase dan tabel skalogram. Data dikumpulkan dengan teknik observasi, wawancara terstruktur dan penyebaran kuesioner serta dokumentasi. Hasil penelitian menunjukkan bahwa kondisi ruang terbuka hijau di Kota Makassar luas dan sebarannya tidak terstruktur mengikuti perkembangan planologis kota. Tiga Kecamatan yang menjadi sampel hanya Kecamatan Ujung Pandang yang mempunyai struktur ruang terbuka hijau yang terpola mengikuti perkembangan pola planologis kota. Sedangkan dua kecamatan lainnya yakni Kecamatan Makassar dan Kecamatan Bontoala tidak mempunyai pola struktur RTH. Kompleks RTH Lapangan Karebosi sebagai RTH tingkat kota luasannya tidak sesuai berdasarkan jumlah penduduk, tingkat pemenuhannya sebesar 18 persen. RTH tingkat kelurahan, dari 12 kelurahan yang menjadi hanya 6 kelurahan yang mempunyai RTH. Fasilitas RTH Tingkat $R W$ dan RT selain RW dan RT yang ditempati RTH tingkat kota, kecamatan dan kelurahan, pada tempat lain tidak ditemukan. Berdasarkan analisis skalogram persentase penyebaran RTH (COR) adalah 24 persen.
\end{abstract}

Kata kunci: Ruang terbuka hijau, Skalogram, Pola Planologis Kota.

\begin{abstract}
This study aims to analyse the green open space in Makassar City from the aspect of the extent and structure of its distribution. The measuring instrument used to see availability and distribution is Permen PU Number 5 the Year 2008. This research was conducted by survey method with descriptive analysis. The analysis technique uses a percentage of tables and scalogram tables. Data collected by observation techniques, structured interviews and questionnaires and documentation. The results showed that the condition of green open space in Makassar City was broad and its distribution was not structured following the urban pathological development, a pathological pattern of the city. While the other two districts, namely Makassar and Bontoala districts, do not have a green open structure pattern. Karebosi Field Green Space Complex as City Level Green Space is not suitable according to population, and the fulfilment rate is 18 per cent. RTH Kelurahan Level, out of 12 villages, only six communities have RTH. Facilities for RW and RT-level green space other than RW and RT occupied by City, Sub-district and Kelurahan Levels, are not found elsewhere. Based on a scalogram analysis, the percentage of green open space is 24 per cent.
\end{abstract}

Keywords: Green open space, skalogram city planological pattern.

\section{PENDAHULUAN}

Jumlah penduduk perkotaan di Indonesia pada tahun 2015 sudah melebihi penduduk yang tinggal di pedesaan [1], kondisi ini akan memberikan implikasi pada tingginya tekanan terhadap pemanfaatan ruang kota [2], akibatnya setiap jengkal lahan perkotaan, bahkan permukaan air seperti sungai, rawa dan pantai dipergunakan untuk membangun sarana dan prasarana kota, sehingga menimbulkan kecenderungan bahwa setiap ada pembangunan dan pemekaran kota akan mengarah menuju maksimalisasi ruang kota, sehingga akibatnya terjadi minimalisasi ruang terbuka hijau kota dan menuju kehidupan artifisial yang sesungguhnya.

Pembangunan kota dan aktivitas yang berlangsung didalamnya merupakan penyumbang terbesar dari masalah lingkungan yang hangat diperbincangkan oleh para ahli lingkungan saat ini, yaitu pemanasan global (global warming) yang disebabkan oleh efek rumah kaca (green house). Diperkirakan dalam seratus tahun terakhir ini, suhu udara rata-rata dunia naik sekitar $0.74 \pm 0.18{ }^{\circ} \mathrm{C}$ dan pada akhir tahun 2100 diperkirakan akan terjadi kenaikan suhu udara bumi sekitar $1,5-4{ }^{\circ} \mathrm{C}$, jika 
tidak dilakukan usaha-usaha nyata dalam rangka menanggulanginya [3].

Meningkatnya proses penangkapan $\mathrm{CO}_{2}$ secara alamiah sangat penting dalam upaya mereduksi gas rumah kaca dan polutan udara lainnya. Diperkirakan dalam 30 tahun terakhir Ruang Terbuka Hijau (RTH) pada kota-kota besar di Indonesia, seperti Jakarta, Bandung, Surabaya, Medan, dan Makassar mengalami penurunan yang cukup signifikan, dari 35 persen pada awal 1970-an menjadi tinggal 10 persen pada saat ini $[4,5,6]$. Menurunnya kuantitas dan kualitas ruang terbuka hijau yang ada di perkotaan, baik berupa ruang terbuka hijau (RTH) dan ruang terbuka non hijau telah mengakibatkan menurunnya kualitas lingkungan perkotaan seperti seringnya terjadi bencana banjir, tingginya polusi udara, dan meningkatnya kerawanan sosial, menurunnya produktivitas masyarakat karena stres akibat terbatasnya ruang terbuka publik [7]. Lebih lanjut dijelaskan pula bahwa kecenderungan terjadinya penurunan ini karena sebagian besar telah dikonversi menjadi infrastruktur perkotaan seperti jaringan jalan, gedung-gedung perkantoran, pusat perbelanjaan, dan kawasan permukiman baru.

Ruang Terbuka Hijau (RTH) mempunyai kegunaan sebagai penyeimbang ekosistem kota, baik itu sistem hidrologi, klimatologi, keanekaragaman hayati, maupun sistem ekologi lainnya, bertujuan meningkatkan kualitas lingkungan hidup, estetika kota, kesehatan, dan kesejahteraan masyarakat (quality of life, human well being). Ruang terbuka hijau yang ideal adalah 30 persen dari luas wilayah kota. Mengacu pada KTT Bumi di Rio de Janeiro, Brazil tahun 1992, dan dipertegas pada KTT Johannesburg, Afrika Selatan 2002 [7].

Pemerintah telah mengeluarkan peraturan perundang-undangan untuk menjadikan lingkungan perkotaan menjadi lingkungan yang nyaman untuk didiami, antara lain yang spesifik mengatur RTH, adalah peraturan Menteri Pekerjaan Umum Nomor 5 Tahun 2008 [8], yang mengatur tentang kebutuhan luasan RTH perkotaan mulai dari tingkat satuan pelayanan RT sampai dengan satuan pelayanan kota, demikian juga pengaturan tentang peletakannya dan komponen-komponen yang ada dalam RTH tersebut.

Mengingat peran RTH yang demikian penting pada lingkungan perkotaan, dan pesatnya perkembangan pembangunan di Kota Makassar, mendorong peneliti untuk melakukan kajian tentang struktur penyebaran RTH di Kota Makassar, dengan menggunakan Permen PU Nomor 5 Tahun 2008 sebagai alat ukur. Hasil dari penelitian ini diharapkan menjadi bahan acuan bagi yang berwenang dalam pengembangan RTH di kota Makassar. dan menjadikannya sebagai kota yang berkelanjutan.

\section{KAJIAN PUSTAKA}

Urbanisasi merupakan pemicu adanya peningkatan jumlah penduduk, kurangnya ketersediaan RTH dan meningkatkan konsumsi energi listrik dimana pada akhirnya akan meningkatkan polusi udara dan efek rumah kaca [9]. Seandainya gas-gas pembentuk atmosfer bumi yang berperan sebagai selimut ini tidak ada, maka seluruh panas bumi dari matahari akan dilepas kembali ke angkasa luar mengakibatkan bumi menjadi beku. Contoh klasik peran $\mathrm{CO}_{2}$ dalam pengaturan suhu atmosfer planet adalah yang terjadi pada planet Venus. Konsentrasi $\mathrm{CO}_{2}$ pada atmosfer Venus sangat tinggi mengakibatkan suhu planet ini demikian tingginya sehingga tidak memungkinkan suatu kehidupan berlangsung didalamnya $[5,10]$.

Berkurangnya jumlah vegetasi persatuan luas tertentu di permukaan bumi akibat pembangunan kota, perumahan, dan pembukaan lahan pertanian, sangat mengurangi jumlah $\mathrm{CO}_{2}$ yang diserap tumbuhan, hal ini memunculkan fenomena alam yang disebut pemanasan bumi (global warming). Kemampuan vegetasi menyerap $\mathrm{CO}_{2}$ di udara dibuktikan oleh penelitian sebelumnya $[3,11]$. Penelitian di lakukan pada wilayah yang beriklim empat musim dan ditemukan, konsentrasi $\mathrm{CO}_{2}$ mencapai titik maksimun pada akhir musim dingin ketika pohon kehilangan seluruh daunnya, serta mencapai titik minimum saat akhir musim panas ketika pohon memiliki kelebatan daun yang tinggi.

Menurut Haq [12], kemampuan tanaman dalam menyerap karbon dioksida telah diketahui melalui penelitian oleh para ahli diantaranya penelitian tentang fungsi tanaman dalam mereduksi polutan disebutkan bahwa Angsana dan Flamboyan dapat mereduksi CO sampai (70\%) dan $\mathrm{SO}_{2}$ sebesar (50\%), Asam Kranji dapat mereduksi CO sampai (80\%) dan $\mathrm{SO}_{2}$ sampai $(90$ \%), Kiara Payung mereduksi $\mathrm{CO}(70 \%)$ dan $\mathrm{SO}_{2}$ sebesar $(60 \%)$, Bougenvile dapat menahan debu sampai $70 \%$. Pohon lain dengan kemampuan penyerapan $\mathrm{CO}_{2}$ yang sangat besar adalah Trembesi, pohon ini mampu menyerap 28.488,39 $\mathrm{kg} \mathrm{CO}_{2}$ /pohon setiap tahunnya.

Hasil penelitian lain dengan temuan yang kurang lebih sama Kusminingrum [13], dengan meneliti potensi tanaman dalam menyerap $\mathrm{CO}_{2}$ dan $\mathrm{CO}$ untuk mengurangi dampak pemanasan global. 
RTH merupakan produsen oksigen yang belum tergantikan fungsinya, menurut Prihandono [14]. Sebagai patokan, pada lahan seluas $1.600 \mathrm{~m}^{2}$, yang terdapat 16 pohon berdiameter tajuk $10 \mathrm{~m}$ mampu menyuplai Oksigen $\left(\mathrm{O}_{2}\right)$ sebesar 14.000-liter per hari. Setiap jam, satu hektar daun-daun hijau dapat menyerap $8 \mathrm{Kg} \mathrm{CO}_{2}$ yang setara dengan $\mathrm{CO}_{2}$ yang dihembuskan oleh nafas manusia sekitar 200 orang dalam waktu yang sama.

Kemampuan pohon dalam memproduksi oksigen dikemukakan juga oleh Kusminingrum [13] bahwa satu batang pohon dapat menyediakan oksigen bagi keperluan bernafas untuk 2 orang. Pada penelitian lain dikatakan 1 (satu) hektar RTH dapat menghasilkan 0.6 ton oksigen untuk konsumsi 1500 orang per hari [15].

Menurut Rawung [16], RTH sebagai komponen penting dari perkotaan diarahkan dikembangkan dalam bentuk jalur hijau, dimana salah satu tanaman yang dapat mereduksi sisa emisi $\mathrm{CO}_{2}$ aktual adalah pohon tanjung dengan kemampuan daya serap 5,04 ton/pohon/tahun. Lebih lanjut dikatakan bawah dalam pemilihan jenis vegetasi mempertimbangkan karakteristik kawasan dan tidak menimbulkan gangguan terhadap aktivitas perkotaan.

RTH diperkotaan digunakan juga sebagai tempat untuk evakuasi jika terjadi bencana alam. Bahkan pada daerah-daerah dengan intensitas bencana alam yang tinggi, RTH dirancang untuk dijadikan sebagai tempat penampungan sementara bagi warga kota yang mengalami bencana, misalnya gempa bumi dan kebakaran. Pada saat bencana terjadi, RTH dapat menjadi tempat yang aman untuk berbagai macam layanan darurat seperti penyediaan persediaan bantuan serta untuk mendirikan pusat komando pelayanan dan bantuan medis [17].

Beberapa kota diluar negeri dalam perencanaan RTH kota mencantumkan jarak tempuh berdasarkan tingkatan RTH, seperti Kota Rotterdam mensyaratkan jarak tempuh maksimal 250 meter untuk RTH pada lokasi perumahan (House Block Greenspace), jarak tempuh maksimal 400 meter untuk RTH bagian kota (Quarter Greenspace) dan jarak tempuh 800 meter untuk RTH wilayah kota (District Greenspace). Pada uraian yang lain dikatakan taman kecil yang luasnya kurang dari 2 (dua) hektar yang dapat ditempuh dengan berjalan kaki dari lingkungan rumah. Taman menengah luasnya 20 ha dengan jarak tempuh 1,5 $\mathrm{Km}$ dari perumahan dan taman besar yang luasnya minimal 60 ha dengan jarak tempuh $8 \mathrm{Km}$ dari perumahan [15].
Pengaturan kebutuhan RTH dan struktur RTH di perkotaan berdasarkan hierarki wilayah diatur dalam Permen PU Nomor 5 Tahun 2008 [8], seperti terlihat pada tabel 1. Tipe RTH diklasifikasikan berdasarkan jumlah penduduk yang akan dilayani, penentuan lokasi yang tepat dan standar luasan minimal. Berdasarkan data tersebut terlihat bahwa jumlah penduduk sangat berperan penting dalam menentukan standar pelayanan RTH.

Penelitian difokuskan pada wilayah pusat kota dengan pertimbangan bahwa wilayah pusat kota mengalami pengembangan pembangunan yang pesat, eksploitasi lahannya sangat tinggi, sehingga diperlukan kajian untuk melihat kondisi penyebaran RTH yang ada didalamnya. Mayoritas RTH di Kota Makassar diambil masuk dalam kategori jenis lapangan yang terkonsentrasi di pusat kota [18].

Tabel 1. Penyediaan RTH Berdasarkan Jumlah Penduduk

\begin{tabular}{|c|c|c|c|c|c|}
\hline No. & $\begin{array}{c}\text { Unit } \\
\text { Lingkungan }\end{array}$ & Tipe RTH & $\begin{array}{c}\text { Luas } \\
\text { Minimal/unit } \\
\text { (m2) }\end{array}$ & $\begin{array}{c}\text { Luas } \\
\text { Minimal } \\
\text { /Kapita } \\
\text { (m2) }\end{array}$ & Lokasi \\
\hline 1 & 250 jiwa & Taman RT & 250 & 1,0 & $\begin{array}{c}\text { Ditengah } \\
\text { Lingkungan RT }\end{array}$ \\
\hline 2 & 2.500 jiwa & Taman RW & 1.250 & 0,5 & $\begin{array}{c}\text { Dipusat Kegiatan } \\
\text { RW }\end{array}$ \\
\hline 3 & 30.000 jiwa & & 9.000 & 0,3 & $\begin{array}{c}\text { Dikelompokkan } \\
\text { dengan } \\
\text { Sekolah/Pusat } \\
\text { Kelurahan }\end{array}$ \\
\hline 4 & 120.000 jiwa & $\begin{array}{c}\text { Taman } \\
\text { Kecamatan }\end{array}$ & 24.000 & 0,2 & $\begin{array}{c}\text { Dikelompokkan } \\
\text { dengan } \\
\text { Sekolah/Pusat } \\
\text { Kecamatan } \\
\end{array}$ \\
\hline & & Pemakaman & Disesuaikan & 1,2 & Tersebar \\
\hline \multirow{3}{*}{5} & \multirow{3}{*}{480.000 jiwa } & Taman Kota & 144.000 & 0,3 & $\begin{array}{c}\text { Dipusat } \\
\text { wilayah/Kota }\end{array}$ \\
\hline & & Hutan Kota & Disesuaikan & 4,0 & $\begin{array}{c}\text { Didalam/Kawasan } \\
\text { pinggiran }\end{array}$ \\
\hline & & $\begin{array}{l}\text { Untuk Fungsi- } \\
\text { fungsi Tertentu }\end{array}$ & Disesuaikan & 12,5 & $\begin{array}{c}\text { Disesuaikan } \\
\text { Kebutuhan }\end{array}$ \\
\hline
\end{tabular}

(Sumber: Permen PU Nomor 5 Tahun, 2008.)

Berdasar pada pertimbangan tersebut sengaja dipilih Kecamatan Ujung Pandang, Kecamatan Makassar dan Kecamatan Bontoala yang dianggap sebagai representasi wilayah pusat kota. Selanjutnya masing-masing kecamatan sengaja dipilih empat kelurahan, yakni Kelurahan Baru, Kelurahan Bulogading, Kelurahan Sawerigading dan Kelurahan Maloku sebagai sampel bagi Kecamatan Ujung Pandang. Kelurahan Maricaya, Kelurahan Sawerigading dan Kelurahan Maloku sebagai sampel bagi Kecamatan Ujung Pandang. 

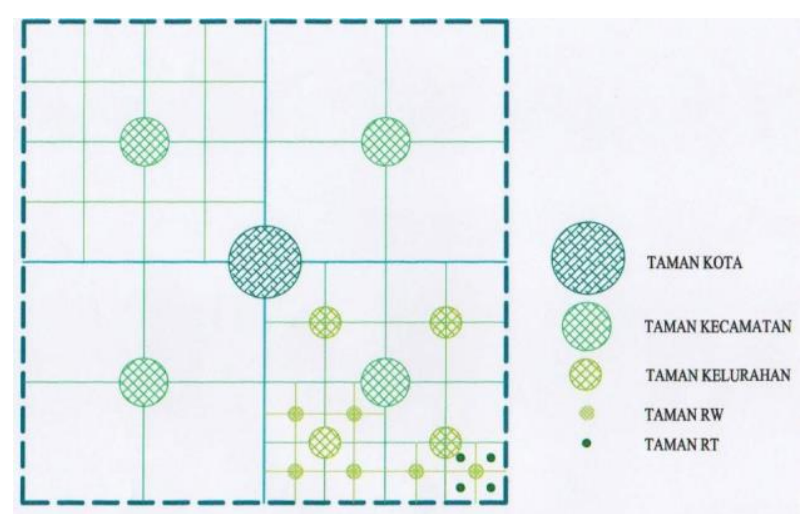

STRUKTUR TAMAN KOTA

DIOLAH dan DMMODIPIKASI BERDASARKAN PERMEN PU NO. 5 TH 2008

(Sumber: Diolah dan Dimodifikasi berdasarkan Permen PU Nomor 5 Tahun, 2008.)

Gambar 1. Model Struktur Penyebaran RTH
Perkotaan

\section{METODE}

Penelitian ini dilaksanakan pada bulan Maret 2016 sampai dengan Mei 2016. Sampel ditentukan dengan mempergunakan metode penentuan sampel bertujuan (Purposive Sampling) dengan memperhatikan adanya RTH yang dapat diamati. Penelitian difokuskan pada wilayah pusat kota dengan pertimbangan bahwa wilayah pusat kota mengalami pengembangan pembangunan yang pesat, eksploitasi lahannya sangat tinggi, sehingga diperlukan kajian untuk melihat kondisi penyebaran RTH yang ada didalamnya.

Berdasar pada pertimbangan tersebut sengaja dipilih Kecamatan Ujung Pandang, Kecamatan Makassar dan Kecamatan Bontoala yang dianggap sebagai representasi wilayah pusat kota. Selanjutnya masing-masing Kecamatan sengaja dipilih empat kelurahan, yakni Kelurahan Baru, Kelurahan Bulogading, Kelurahan Sawerigading dan Kelurahan Maloku sebagai sampel bagi Kecamatan Ujung Pandang. Kelurahan Maricaya, Kelurahan Sawerigading dan Kelurahan Maloku sebagai sampel bagi Kecamatan Ujung Pandang. Kelurahan Maricaya, Kelurahan Maradekaya, Kelurahan Bara-Baraya Utara dan Kelurahan Lariang Bangi sebagai sampel bagi Kecamatan Makassar. Kelurahan Gaddong, Kelurahan Wajo Baru, Kelurahan Baraya dan Kelurahan Bontoala sebagai sampel bagi Kecamatan Bontoala, kemudian masing-masing kelurahan sengaja dipilih satu RW dan satu RT.

Teknik analisis mempergunakan teknik analisis persentase yang menggambarkan RTH lapangan dan RTH berdasarkan Permen PU Nomor 5 Tahun 2008 [8], serta RTH berdasarkan jumlah penduduk berdasarkan hierarki wilayah. Teknik analisis selanjutnya yang dipergunakan adalah teknik analisis tabel skalogram untuk melihat hierarki ketersediaan RTH untuk masing-masing unit wilayah sekaligus menggambarkan struktur penyebarannya.

Teknik skalogram merupakan salah satu alat analisis yang dipakai untuk menilai tingkat hierarki kelengkapan dan keterlaksanaan fungsi fasilitas suatu unit lingkungan. Teknik analisis skalogram ini banyak dipakai oleh para geograf, demograf dan perencana untuk menganalisis tingkat hierarki ketersediaan fasilitas di perkotaan, Rondinelli [19]. Berdasarkan gambaran tabel skalogram dapat dihitung COR (Coeffisient of Refroducibility) yaitu angka persentase dari hasil bagi antara jumlah sel tabel yang terisi dengan jumlah sel tabel keseluruhan. Dalam bentuk persamaan dapat digambarkan:

$\mathrm{COR}=(\mathrm{A} / \mathrm{Q}) \times 100$, dengan keterangan simbol

$\mathrm{A} \quad=$ Jumlah sel tabel yang terisi

$\mathrm{Q} \quad=$ Jumlah sel tabel secara keseluruhan

\section{HASIL DAN PEMBAHASAN}

\section{Sebaran RTH di Kecamatan Ujung Pandang}

Berdasarkan hasil survei sebaran RTH di Kecamatan Ujung Pandang berdasarkan sampel Kelurahan seperti terlihat pada tabel 2.

Terlihat pada tabel 2, Kelurahan Baru memiliki RTH Kompleks Lapangan Karebosi, dilihat dari perletakannya dalam hirarki wilayah Kota, RTH ini disamping sebagai RTH Kelurahan untuk Kelurahan Baru, juga berfungsi sebagai RTH Tingkat Kecamatan untuk Kecamatan Ujung Pandang dan RTH Kota untuk Kota Makassar. Berdasarkan luasan yang ada, maka RTH untuk Tingkat Kelurahan dan Tingkat Kecamatan sangat memenuhi bahkan melebihi luasan yang diatur dalam Permen PU Nomor 5 Tahun 2008 [8].

Dilihat dari aspek jumlah penduduk, Kecamatan Ujung Pandang dengan jumlah penduduk 27.160 jiwa, dengan standar RTH Kecamatan 0,2 $\mathrm{m}^{2}$ per penduduk maka $\mathrm{RTH}$ Tingkat Kecamatan yang harus ada seluas $5.432 \mathrm{~m}^{2}$, sedangkan untuk Kelurahan Baru dengan jumlah penduduk 1.558 jiwa, dengan standar RTH $0,3 \mathrm{~m}^{2}$ per penduduk, maka RTH Tingkat Kelurahan yang harus ada seluas $467 \mathrm{~m}^{2}$.

Jika dilihat berdasarkan luas wilayah, luas Kelurahan Baru sebesar $21 \mathrm{Ha}$ atau $210.000 \mathrm{~m}^{2}$, jika 30 persen dari luas tersebut adalah $\mathrm{RTH}$, maka Kelurahan Baru seharusnya mempunyai RTH seluas $63.000 \mathrm{~m}^{2}$. Jika $20 \%$ dari RTH tersebut adalah RTH yang harus disediakan oleh pemerintah, 
maka luasnya adalah $42.000 \mathrm{~m}^{2}$. Sepuluh persen sisa RTH adalah bagian dari partisipasi masyarakat dalam bentuk RTH halaman rumah dan halaman perkantoran dan dikategorikan sebagai RTH pribadi. Berdasarkan uraian dari aspek jumlah penduduk dan luas wilayah dan peraturan pemerintah, terlihat bahwa RTH Tingkat Kecamatan dan RTH tingkat kelurahan untuk Kelurahan Baru dibanding luas RTH Kompleks Lapangan Karebosi sangat memenuhi.

Berdasarkan uraian dari aspek jumlah penduduk terlihat bahwa RTH Tingkat Kecamatan dan RTH Tingkat Kelurahan untuk Kelurahan Baru dibanding luas RTH Kompleks Lapangan Karebosi sangat memenuhi. Dari analisis RTH berdasarkan jumlah penduduk terlihat adanya perbedaan luas yang cukup besar dengan RTH seperti yang diatur dengan Permen PU Nomor 5 Tahun 2008 [8]. Perbedaan ini disebabkan oleh adanya perbedaan yang cukup besar antara jumlah penduduk menurut hierarki kota yang diatur oleh Permen PU Nomor 5 Tahun 2008 [8] dengan jumlah penduduk yang ada di lapangan.

Di Kelurahan Sawerigading terdapat RTH Lapangan Hasanuddin, dilihat dari sisi luasan, RTH ini memenuhi persyaratan sebagai RTH Tingkat Kelurahan untuk Kelurahan Sawerigading seperti yang diatur dalam Permen PU Nomor 5 Tahun 2008. Jika dilihat dari aspek jumlah penduduk dengan jumlah penduduk sebanyak 1.585 jiwa, maka RTH Tingkat Kelurahan yang harus ada seluas $476 \mathrm{~m}^{2}$. Jika luas ini dibandingkan dengan luasan RTH Lapangan Hasanuddin, maka untuk Kelurahan Sawerigading RTH Tingkat Kelurahannya sangat memenuhi.

Jika dilihat berdasarkan luas wilayah Kelurahan Sawerigading yang luasnya $41 \mathrm{Ha}$ atau $410.000 \mathrm{~m}^{2}$, jika 30 persen dari luas tersebut adalah RTH, maka RTH yang dibutuhkan adalah 123.000 $\mathrm{m}^{2}$. Kalau 20 persen dari luas ini merupakan kewajiban pemerintah, maka RTH yang harus disediakan adalah $82.000 \mathrm{~m}^{2}$. Jika luas ini dibandingkan dengan luas RTH Lapangan Hasanuddin yang luasnya $19.000 \mathrm{~m}^{2}$ tidak memenuhi.

Di Kelurahan Bulogading terdapat 5 lokasi RTH, 3 lokasi yaitu RTH Taman Macan, Taman Pattimura dan Taman Benteng merupakan RTH aktif dengan pengertian RTH ini dapat akses oleh warga Kelurahan Bulogading untuk beraktivitas didalamnya, sedangkan RTH Taman Slamet Riadi sebagai RTH pasif atau RTH bukan untuk beraktivitas diatasnya. Berdasarkan luasan yang ada RTH Taman Macan memenuhi persyaratan sebagai
RTH Tingkat Kelurahan untuk Kelurahan Bulogading.

Jika dilihat dari aspek jumlah penduduk Kelurahan Bulogading, dengan jumlah penduduk sebanyak 2.703 jiwa, seharusnya mempunyai RTH tingkat Kelurahan seluas $811 \mathrm{~m}^{2}$. Dari aspek jumlah penduduk dikaitkan dengan luas RTH yang dimiliki oleh Kelurahan Bulogading maka luas RTH Tingkat Kelurahannya sangat memenuhi. Sedangkan jika dilihat dari luas wilayah dengan kewajiban pemerintah menyiapkan 20 persen atau seluas $46.000 \mathrm{~m}^{2}$, dari aspek ini RTH di Kelurahan Bulogading tidak memenuhi

Di Kelurahan Maloku terdapat RTH Taman Hasanuddin. Berdasarkan luasan yang ada RTH ini tidak memenuhi luasan RTH tingkat kelurahan seperti yang diatur dalam Permen PU Nomor 5 Tahun 2008 [8]. Jika dilihat dari aspek jumlah penduduk Kelurahan Maloku, dengan jumlah penduduk sebanyak 2.531 jiwa, seharusnya mempunyai RTH tingkat Kelurahan seluas 759 M2. Dari aspek jumlah penduduk dikaitkan dengan luas RTH yang dimiliki oleh Kelurahan Maloku maka luas RTH Tingkat Kelurahannya sangat memenuhi. Berdasarkan analisis ini terlihat bahwa Di Kelurahan Maloku, RTH Tingkat Kelurahan luasnya tidak mencukupi berdasarkan Permen PU Nomor 5 Tahun 2008 [8], sedangkan jika dilihat dari sisi jumlah penduduk sangat memenuhi.

Jika dilihat berdasarkan luas wilayah di Kelurahan Maloku, seharusnya mempunyai RTH seluas $60.000 \mathrm{~m}^{2}$ dengan acuan 30 persen dari luas wilayah adalah RTH. Kalau 20 persen dari RTH tersebut adalah kewajiban pemerintah, maka pemerintah harus menyiapkan RTH seluas 40,000 $\mathrm{m}^{2}$. RTH Taman Hasanuddin seluas $7.050 \mathrm{~m}^{2}$, maka persaratan RTH di kelurahan ini tidak memenuhi.

Dilihat dari aspek penyediaan RTH untuk tingkat RW dan tingkat RT berdasarkan hasil survei didapatkan, selain RW dan RT yang ditempati RTH tingkat kelurahan di Kelurahan Baru, Kelurahan Sawerigading, Kelurahan Bulogading dan Kelurahan Maloku, tidak ditemukan adanya fasilitas RTH pada RW dan RT di lokasi lain.

Dilihat dari aspek penyebaran RTH di Kecamatan Ujung Pandang, berdasarkan survei terlihat dari empat Kelurahan yang menjadi sampel, masing-masing Kelurahan mempunyai RTH Tingkat Kelurahan. Penyebarannya terlihat mengikuti pola perkembangan planologi dan terstruktur menurut hierarki wilayah RTH Tingkat Kecamatan dan RTH Tingkat Kelurahan. Terciptanya pola planologis RTH di Kecamatan Ujung Pandang merupakan bagian dari fasilitas 
lingkungan yang sengaja diadakan oleh Pemerintah Kolonial Belanda yang pada saat itu menguasai Makassar.

\section{Sebaran RTH di Kecamatan Makassar}

Berdasarkan hasil survei sebaran RTH di Kecamatan Makassar berdasarkan sampel Kelurahan seperti terlihat pada tabel 3. Terlihat pada tabel 3 di Kelurahan Maradekaya terdapat RTH Taman P2KH Kerung-Kerung seluas $5.000 \mathrm{~m}^{2}$. Berdasarkan luasan RTH menurut Permen PU Nomor 5 Tahun 2008 [8] tidak mencukupi sebagai RTH Tingkat Kelurahan. Namun jika dilihat dari aspek jumlah penduduk Kelurahan Maradekaya yang jumlahnya 5.909 jiwa seharusnya mempunyai RTH Tingkat Kelurahan seluas $1.77,7 \mathrm{~m}^{2}$, maka RTH Taman P2KH Kerung-Kerung memenuhi sebagai RTH Tingkat Kelurahan. Sedangkan jika dilihat berdasarkan luas wilayah seharusnya mempunyai RTH seluas $39.000 \mathrm{~m}^{2}$ dengan acuan 30 persen dari luas wilayah adalah RTH. Berdasarkan angka tersebut sangat tidak memenuhi.

RTH ini merupakan bantuan Pemerintah Pusat, merupakan bagian dari Program Pengembangan Kota Hijau. Didalamnya dibangun unsur-unsur yang merepresentasikan hal-hal yang menjadi perhatian dari Program Kota Hijau, seperti Hijau Energi, Hijau Transportasi, Hijau Pedestrian, dan Hijau Air. Hijau energi diimplementasikan dengan pemakaian energi matahari untuk menghasilkan energi listrik sedangkan hijau air dengan membuat sumur resapan sebagai wadah penampung dan peresapan air yang bisa membantu dalam penyediaan air di musim kemarau.

Pengembangan RTH ini menjadi RTH tingkat kecamatan sangat memungkinkan dilakukan mengingat masih adanya lahan kosong disekitarnya milik Pemerintah Kota Makassar. Dilihat dari posisinya dari Jalan Kerung-Kerung RTH ini tidak terlihat, karena letaknya yang cukup jauh kedalam dan tertutup oleh bangunan Kantor UPTD penyedotan tinja. Kondisi ini juga yang menyebabkan tidak maksimalnya warga Kelurahan Maradekaya mempergunakan RTH ini.

Tiga kelurahan lainnya yang menjadi sampel yaitu Kelurahan Maricaya, Kelurahan Lariang Bangi dan Kelurahan Bara-Baraya Utara tidak ditemukan adanya RTH Tingkat Kelurahan. Demikian juga untuk RTH Tingkat RW dan RT selain RW dan RT yang ditempati RTH P2KH Kerung-kerung, tidak ditemukan adanya RTH Tingkat RW dan RT di tempat lain.

RTH jenis lain yang terdapat di Kecamatan Makassar dengan pepohonan yang cukup baik adalah RTH jalur jalan yang terdapat di Jalan Urip Sumoharjo, RTH Jalur Jalan Latimojong, RTH jalur Jalan Sungai Saddang, RTH jalur Jalan Monginsidi, RTH jalur Jalan Kerung-Kerung dan RTH jalur Jalan Veteran.

Berdasarkan deskripsi RTH di Kecamatan Makassar, terlihat bahwa untuk RTH tingkat kecamatan tidak di temukan, sedangkan untuk tingkat kelurahan dari empat kelurahan yang menjadi sampel, hanya satu Kelurahan yang mempunyai RTH tingkat kelurahan. Tidak ditemukan adanya penyebaran RTH baik untuk RTH Tingkat Kelurahan maupun untuk RTH Tingkat RW dan RT. Dilihat dari posisi peletakan dan pengelompokan dengan fasilitas kota lainnya, terlihat RTH ini berada pada kelompok fasilitas kota yang tidak mendukung, yaitu berada pada kawasan UPTD penyedotan tinja.

\section{Sebaran RTH di Kecamatan Bontoala}

Berdasarkan hasil survei sebaran RTH di Kecamatan Bontoala berdasarkan sampel Kelurahan seperti terlihat pada tabel 4. Terlihat pada tabel 4, di Kelurahan Wajo Baru terdapat RTH Taman Maccini dengan luas $3.400 \mathrm{~m}^{2}$. Berdasarkan luasnya tidak sesuai dengan luas RTH Tingkat Kelurahan yang diatur dalam Permen PU [8]. Dilihat dari aspek jumlah penduduk, Kelurahan Wajo Baru berpenduduk 4.646 jiwa, membutuhkan RTH Tingkat Kelurahan seluas $1.394 \mathrm{~m}^{2}$. Jadi jika dilihat dari aspek jumlah penduduk RTH Maccini bisa dikategorikan sebagai RTH Tingkat Kelurahan di Kelurahan Wajo Baru. Namun jika dilihat dari fasilitas yang ada didalamnya RTH ini tidak diperuntukkan sebagai RTH unit lingkungan yang bisa dipergunakan oleh warga sekitar untuk bersantai. Jika dilihat berdasarkan luas wilayah, luas RTH yang harus disediakan oleh pemerintah berdasarkan amanat undang-undang sebesar 20 persen atau seluas $26.000 \mathrm{~m}^{2}$. Jika luas ini dibanding dengan luas RTH Maccini sangat tidak mencukupi.

RTH Maccini termasuk RTH pasif, karena tidak ada fasilitas RTH didalamnya yang memungkinkan orang untuk beraktivitas. RTH ini menempati posisi yang sangat strategis, pada ujung sumbu axis kota dari arah timur dan bisa dikembangkan menjadi RTH penyambut dalam memasuki kawasan inti kota. Tiga kelurahan lainnya yang menjadi sampel yaitu Kelurahan Gaddong, Kelurahan Bontoala dan Kelurahan Baraya tidak ditemukan adanya Fasilitas RTH Tingkat Kelurahan.

Di Kelurahan Baraya terdapat halaman Masjid Al Markas yang bisa di kembangkan menjadi 
fasilitas RTH. Berdekatan dengan Masjid Al Markas juga terdapat lahan kosong eks Aula Fakultas Kedokteran Universitas Hasanuddin yang juga bisa dikembangkan menjadi RTH. Lahan ini sangat potensial dikembangkan menjadi RTH tingkat kecamatan, dan berada pada kawasan bangunan yang saling menunjang jika dikembangkan sebagai RTH. Selain RTH yang telah disebutkan di Kecamatan Bontoala juga terdapat RTH jenis jalur hijau jalan. RTH jenis ini terdapat di Jalan Andalas, Jalan Bandang, Jalan Mesjid Raya, Jalan Gunung Latimojong dan Jalan Veteran Utara dengan kondisi pertumbuhan pohon yang cukup lebat.

Berdasarkan gambaran deskripsi RTH di Kecamatan Bontoala, terlihat bahwa Kecamatan Bontoala tidak mempunyai struktur RTH yang tersusun dan tersebar menurut jenjang hierarki wilayah seperti yang diatur dalam Permen PU Nomor 5 Tahun 2008 [8]. Jika sebaran RTH dilihat berdasarkan RTH tingkat kecamatan dan kota, maka hasil analisisnya seperti terlihat pada tabel 5 . Terlihat pada tabel 5, RTH tingkat kecamatan hanya terdapat di Kecamatan Ujung Pandang, sedangkan untuk Kecamatan Makassar dan Kecamatan Bontoala tidak memiliki RTH tingkat kecamatan.

Berdasarkan Permen PU Nomor 5 Tahun 2008

[8], Kecamatan Makassar dan Kecamatan Bontoala membutuhkan RTH tingkat Kecamatan seluas $24.000 \mathrm{~m}^{2}$, sedangkan berdasarkan jumlah penduduk Kecamatan Makassar membutuhkan
$16.496 \mathrm{~m}^{2}$, sedangkan Kecamatan Bontoala membutuhkan $10.943 \mathrm{~m}^{2}$.

Jika dilihat penyediaan RTH Tingkat Kota, terlihat adanya kekurangan yang cukup besar. Kompleks Lapangan Karebosi yang dikategorikan sebagai RTH tingkat kota luasnya hanya $73.000 \mathrm{~m}^{2}$, sedangkan berdasarkan jumlah penduduk RTH tingkat kota yang dibutuhkan seluas $405.641 \mathrm{~m}^{2}$, tingkat pemenuhannya hanya 18 persen.

Berdasar pada uraian kebutuhan RTH tingkat kecamatan dan RTH tingkat kota, maka Pemerintah Kota Makassar sesuai amanat undang-undang berkewajiban mengadakan RTH yang belum ada. Pemenuhan RTH ini juga demi terciptanya lingkungan Kota Makassar menjadi nyaman ditempati, yang pada gilirannya menciptakan kondisi kehidupan warga kota yang dinamis dan produktif.

Berdasarkan kondisi RTH per kecamatan seperti telah diuraikan sebelumnya, maka secara tabel skalogram dapat digambarkan tingkat ketersediaan RTH berdasarkan kecamatan dan berdasarkan tingkat unit RTH seperti pada tabel 6 . Terlihat pada tabel 6, Kecamatan Ujung Pandang menempati urutan teratas dalam sebaran RTH menurut unit lingkungan, sedangkan jika dilihat berdasarkan jenis RTH yang ada dalam masingmasing unit wilayah, terlihat RTH Tingkat Kelurahan merupakan jenis RTH yang terbanyak, disusul RTH jenis Jalur Jalan. Persentase sebaran berdasarkan sampel yang diamati sebesar 24 persen.

Tabel 2. Sebaran RTH Menurut Kelurahan di Kecamatan Ujung Pandang

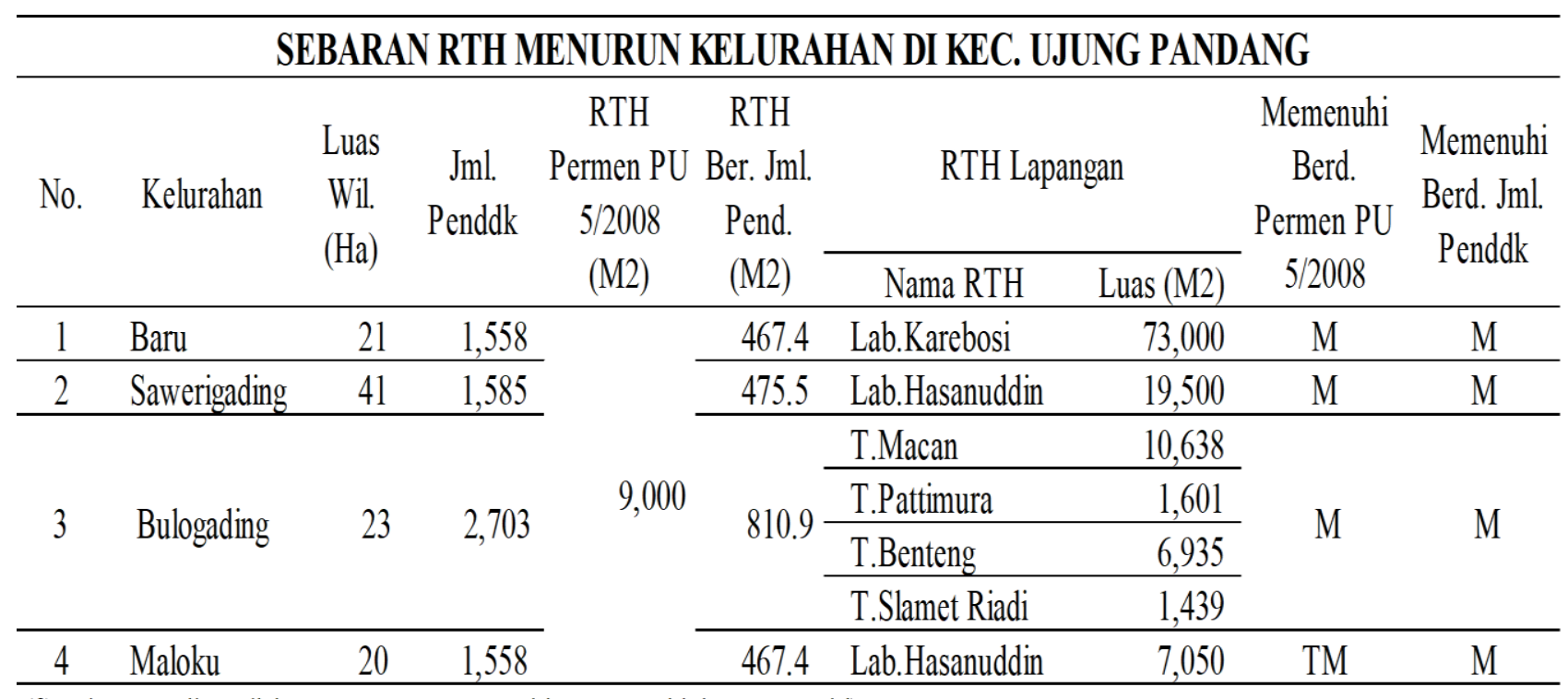

(Sumber: Hasil analisis, Ket: M = Memenuhi, TM = Tidak Memenuhi) 
Tabel 3. Sebaran RTH Berdasarkan Kelurahan di Kecamatan Makassar

\begin{tabular}{|c|c|c|c|c|c|c|c|c|c|}
\hline \multicolumn{10}{|c|}{ SEBARAN RTH MENURUN KELURAHAN DI KEC. MAKASSAR } \\
\hline \multirow{2}{*}{ No. } & \multirow{2}{*}{ Kelurahan } & \multirow{2}{*}{$\begin{array}{l}\text { Luas } \\
\text { Wil. } \\
(\mathrm{Ha})\end{array}$} & \multirow{2}{*}{$\begin{array}{c}\text { Jml. } \\
\text { Penddk }\end{array}$} & \multirow{2}{*}{$\begin{array}{c}\text { RTH } \\
\text { Permen PU } \\
5 / 2008 \\
\text { (M2) } \\
\end{array}$} & \multirow{2}{*}{$\begin{array}{c}\text { RTH } \\
\text { Ber. Jml. } \\
\text { Pend. } \\
\text { (M2) } \\
\end{array}$} & \multicolumn{2}{|c|}{ RTH Lapangan } & \multirow{2}{*}{$\begin{array}{l}\text { Memenuhi } \\
\text { Berd. } \\
\text { Permen PU } \\
5 / 2008 \\
\end{array}$} & \multirow{2}{*}{$\begin{array}{l}\text { Memenuh } \\
\text { Berd. Jml. } \\
\text { Penddk }\end{array}$} \\
\hline & & & & & & Nama RTH & Luas (M2) & & \\
\hline 1 & Maricaya & 26 & 5.901 & \multirow{4}{*}{9.000} & 1.770 & - & - & $\mathrm{TM}$ & $\mathrm{TM}$ \\
\hline 2 & Maradekaya & 13 & 4.209 & & 1.263 & $\begin{array}{l}\text { T. Kerung-Kerung } \\
\text { (P2KH) }\end{array}$ & 5.000 & TM & M \\
\hline 3 & Bara-Baraya Utara & 11 & 5.909 & & 1.773 & - & - & TM & $\mathrm{TM}$ \\
\hline 4 & Lariang Bangi & 20 & 4.446 & & 1.334 & - & - & $\mathrm{TM}$ & $\mathrm{TM}$ \\
\hline
\end{tabular}

(Sumber: Hasil analisis, Ket: M = Memenuhi, TM = Tidak Memenuhi)

Tabel 4. Sebaran RTH Berdasarkan Kelurahan di Kecamatan Bontoala

\begin{tabular}{|c|c|c|c|c|c|c|c|c|c|}
\hline \multicolumn{10}{|c|}{ SEBARAN RTH MENURUN KELURAHAN DI KEC. BONTOALA } \\
\hline \multirow{2}{*}{ No. } & \multirow{2}{*}{ Kelurahan } & \multirow{2}{*}{$\begin{array}{l}\text { Luas } \\
\text { Wil. } \\
(\mathrm{Ha})\end{array}$} & \multirow{2}{*}{$\begin{array}{c}\text { Jml. } \\
\text { Penddk }\end{array}$} & \multirow{2}{*}{$\begin{array}{c}\text { RTH } \\
\text { Permen PU } \\
5 / 2008 \\
\text { (M2) }\end{array}$} & \multirow{2}{*}{$\begin{array}{c}\text { RTH } \\
\text { Ber. Jml. } \\
\text { Pend. } \\
\text { (M2) }\end{array}$} & \multicolumn{2}{|c|}{ RTH Lapangan } & \multirow{2}{*}{$\begin{array}{l}\text { Memenuhi } \\
\text { Berd. } \\
\text { Permen PU } \\
5 / 2008 \\
\end{array}$} & \multirow{2}{*}{$\begin{array}{c}\text { Memenuh } \\
\text { Berd. Jml. } \\
\text { Penddk }\end{array}$} \\
\hline & & & & & & Nama RTH & Luas (M2) & & \\
\hline 1 & Gaddong & 25 & 4,335 & \multirow{4}{*}{9,000} & 1,301 & - & - & $\mathrm{TM}$ & $\mathrm{TM}$ \\
\hline 2 & Wajo Baru & 13 & 4,646 & & 1,394 & Taman Maccini & 3,400 & $\mathrm{TM}$ & $\mathrm{M}$ \\
\hline 3 & Baraya & 21 & 5,806 & & 1,742 & - & - & $\mathrm{TM}$ & TM \\
\hline 4 & Bontoala & 13 & 1,836 & & 551 & - & - & $\mathrm{TM}$ & $\mathrm{TM}$ \\
\hline
\end{tabular}

(Sumber: Hasil analisis, Ket: M = Memenuhi, TM = Tidak Memenuhi)

Tabel 5. Sebaran RTH Kecamatan dan Kota

\begin{tabular}{|c|c|c|c|c|c|c|c|c|c|}
\hline \multirow{2}{*}{ No. } & \multirow{2}{*}{$\begin{array}{c}\text { Nama Kecamatan } \\
\text { dan Kota }\end{array}$} & \multirow{2}{*}{$\begin{array}{l}\text { Luas } \\
\text { Wil. } \\
(\mathrm{Ha})\end{array}$} & \multirow{2}{*}{ Jml. Penddk } & \multirow{2}{*}{$\begin{array}{c}\text { RTH } \\
\text { Permen } \\
\text { PU } \\
5 / 2008 \\
(\mathrm{M} 2) \\
\end{array}$} & \multirow{2}{*}{$\begin{array}{l}\text { RTH Jml. } \\
\text { Pend. } \\
\text { (M2) }\end{array}$} & \multicolumn{2}{|c|}{ RTH Lapangan } & \multirow{2}{*}{$\begin{array}{l}\text { Memenuhi } \\
\text { Berd. } \\
\text { Permen PU } \\
-\quad 5 / 2008\end{array}$} & \multirow{2}{*}{$\begin{array}{c}\text { Memenuhi } \\
\text { Berd. Jml. } \\
\text { Penddk }\end{array}$} \\
\hline & & & & & & Nama RTH & Luas (1 & & \\
\hline 1 & Kec. U. Pandang & 263 & 27,160 & \multirow{3}{*}{24,000} & 5,432 & Lap. Karebosi & 73,000 & M & M \\
\hline 2 & Kec. Makassar & 252 & 82,478 & & 16,496 & - & - & - & - \\
\hline 3 & Kec. Bontoala & 210 & 54,714 & & 10,943 & - & - & - & - \\
\hline 4 & Kota Makassar & 17,577 & $1,352,136$ & $0.3 /$ org & 405,641 & Lap. Karebosi & 73,000 & $\mathrm{TM}$ & $\mathrm{TM}$ \\
\hline
\end{tabular}

(Sumber: Hasil analisis, Ket: M = Memenuhi, TM = Tidak Memenuhi) 
Tabel 6. Skalogram Sebaran RTH

\begin{tabular}{|c|c|c|c|c|c|c|c|c|c|c|c|}
\hline No & & Unit Wilayah & 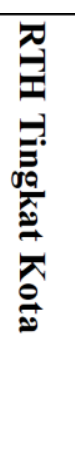 & 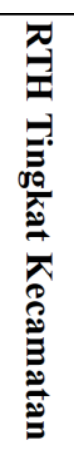 & 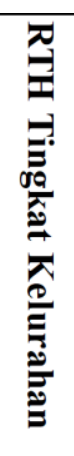 & 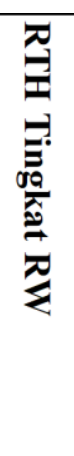 & 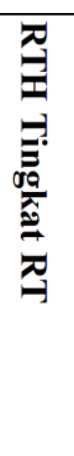 & 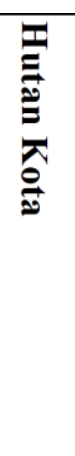 & 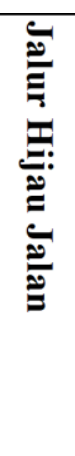 & 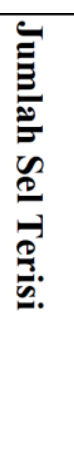 & Keterangan \\
\hline \multirow{4}{*}{1} & \multirow{4}{*}{ 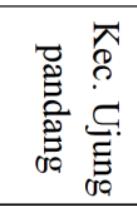 } & Kelurahan Baru & \multirow{12}{*}{$\mathbf{x}$} & \multirow{4}{*}{$\mathbf{x}$} & $\mathbf{x}$ & - & - & \multirow{4}{*}{-} & \multirow{4}{*}{$\mathbf{x}$} & \multirow{4}{*}{7} & \multirow{4}{*}{ Ranking I } \\
\hline & & Kelurahan Sawerigading & & & $\mathbf{x}$ & - & - & & & & \\
\hline & & Kelurahan Bulogading & & & $\mathbf{x}$ & - & - & & & & \\
\hline & & Kelurahan Maloku & & & $\mathbf{x}$ & - & - & & & & \\
\hline \multirow{4}{*}{2} & \multirow{4}{*}{ 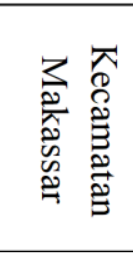 } & Kelurahan Maricaya & & & - & - & - & \multirow{4}{*}{-} & \multirow{4}{*}{$\mathbf{x}$} & \multirow{4}{*}{2} & \multirow{4}{*}{ Ranking II } \\
\hline & & Kelurahan Maradekaya & & & $\mathbf{x}$ & - & - & & & & \\
\hline & & $\begin{array}{l}\text { Kelurahan Bara-Baraya } \\
\text { utara }\end{array}$ & & & - & - & - & & & & \\
\hline & & Kelurahan Lariang Bangi & & & - & - & - & & & & \\
\hline \multirow{4}{*}{3} & \multirow{4}{*}{ 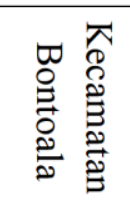 } & Kelurahan Gaddong & & & - & - & - & \multirow{4}{*}{ - } & \multirow{4}{*}{$\mathbf{x}$} & \multirow{4}{*}{2} & \multirow{4}{*}{ Ranking III } \\
\hline & & Kelurahan Wajo Baru & & & $\mathbf{x}$ & - & - & & & & \\
\hline & & Kelurahan Baraya & & & - & - & - & & & & \\
\hline & & Kelurahan Bontoala & & & - & - & - & & & & \\
\hline \multicolumn{3}{|c|}{ Jumlah Sel Terisi (A) } & 1 & 1 & 6 & 0 & 0 & 0 & 3 & 11 & \\
\hline \multirow{2}{*}{\multicolumn{3}{|c|}{$\begin{array}{c}\text { Rangking } \\
\text { Jumlah Sel Keseluruhan }(\mathrm{Q})\end{array}$}} & III & III & I & IV & IV & III & II & & \\
\hline & & & \multicolumn{9}{|c|}{46} \\
\hline \multicolumn{3}{|c|}{$\mathrm{COR}=(\mathrm{A} / \mathrm{Q}) \times 100$} & \multicolumn{9}{|c|}{24 Persen } \\
\hline
\end{tabular}

\section{KESIMPULAN DAN SARAN}

RTH di Kota Makassar tidak tersebar mengikuti pola perkembangan struktur planologis kota seperti yang diatur dalam Permen PU Nomor 5 Tahun 2008. Dari tiga kecamatan yang menjadi sampel hanya Kecamatan Ujung Pandang yang mempunyai struktur RTH yang tersusun menurut jenjang hierarki wilayah sampai jenjang tingkat kelurahan. RTH tingkat RW dan RT tidak teridentifikasi pada semua sampel. Kompleks Lapangan Karebosi yang dikategorikan sebagai RTH tingkat kota dari sisi luasan belum mencukupi berdasarkan Permen PU Nomor 5 Tahun 2008. Kota Makassar seharusnya mempunyai RTH tingkat kota berdasarkan jumlah penduduk seluas $405.641 \mathrm{~m}^{2}$, sedangkan yang tersedia hanya $73.000 \mathrm{~m}^{2}$, jadi persentase pemenuhannya 18 persen. Disarankan melakukan penelitian sejenis pada kota-kata lain.

\section{DAFTAR PUSTAKA}

[1] Dimyati M (2010) Mengatasi Backlog Perumahan Bagi Masyarakat Perkotaan. Peminat Masalah Tata Ruang dan Perkotaan, bekerja di Kemenpera Vol. 3.

[2] Alabi MO, Planning R (2009) Revitalizing urban public open spaces, through vegetative enclaves in Lokoja, Nigeria. Journal of Geography Vol. 2, Issue 3: pp. 051-054.

[3] Karyono TH (2010) Green Architecture: Pengantar Pemahaman Arsitektur Hijau di Indonesia. Jakarta: Rajawali Pers.

[4] Joga N (2013) RTH 30 Persen Resolusi Kota Hijau: Gramedia Pustaka Utama.

[5] Hastuti E, Utami T (2008) Potensi Ruang Terbuka Hijau dalam Penyerapan Co2 Di Permukiman Studi Kasus: Perumnas Sarijadi Bandung dan Cirebon. Jurnal Permukiman Vol. 3, Issue 2: pp. 106-114.

[6] Hastuti E (2011) Kajian perencanaan ruang terbuka hijau (RTH) perumahan sebagai bahan revisi SNI 03-17332004. Jurnal Standardisasi Vol. 13, Issue 1: pp. 36-44. 
[7] Dwiyanto A (2009) Kuantitas dan Kualitas Ruang Terbuka Hijau (RTH) di permukiman Kota. Jurnal Nasional Arsitektur.

[8] Umum MP (2008) Peraturan Menteri Pekerjaan Umum No. 5 Tahun 2008 tentang Pedoman Penyediaan dan Pemanfaatan Ruang Terbuka Hijau di Kawasan Perkotaan.

[9] Kurniati AC, Nitiivattananon V, Sulistyarso H (2017) Faktor-Faktor Yang Mempengaruhi Urban Heat Island Di Surabaya, Indonesia; 2017. pp. 1036-1045.

[10] Roaf S, Roaf S, Crichton D, et al. (2009) Adapting buildings and cities for climate change: a 21st century survival guide: Routledge.

[11] Keeling CD, Whorf TP, Wahlen M, et al. (1995) Interannual extremes in the rate of rise of atmospheric carbon dioxide since 1980. Nature Vol. 375, Issue 6533: pp. 666.

[12] Haq SMA (2011) Urban green spaces and an integrative approach to sustainable environment. Journal of environmental protection Vol. 2, Issue 05: pp. 601.

[13] Kusminingrum N (2008) Potensi tanaman dalam menyerap CO2 dan CO untuk mengurangi dampak pemanasan global. Jurnal Permukiman Vol. 3, Issue 2: pp. 96-105.

[14] Prihandono A (2010) Penyediaan Ruang Terbuka Hijau (RTH) Menurut UU No. 26/2007 tentang Penataan Ruang dan Fenomena Kebijakan Penyediaan RTH Di Daerah. Jurnal Permukiman Vol. 5, Issue 1: pp. 13-23.

[15] Hakim R, Utomo H (2012) Komponen Perancangan Arsitektur Lansekap: prinsip-unsur dan aplikasi desain: PT Bumi Aksara.

[16] Rawung FC (2015) Efektivitas Ruang Terbuka Hijau (RTH) Dalam Mereduksi Emisi Gas Rumah Kaca (GRK) di Kawasan Perkotaan Boroko. Media Matrasain Vol. 12, Issue 2: pp. 17-32.

[17] Fan L, Xue S, Liu G (2012) Patterns and its disaster shelter of urban green space: Empirical evidence from Jiaozuo city, China. African Journal of Agricultural Research Vol. 7, Issue 7: pp. 1184-1191.

[18] Dollah AS, Rasmawarni R (2018) Analisis Ruang Terbuka Hijau (RTH) Dari Aspek Keterlaksanaan Fungsi Sosial Di Kota Makassar. Jurnal LINEARS Vol. 1, Issue 2: pp. 62-71.

[19] Rondinelli DA (2019) Applied methods of regional analysis: the spatial dimensions of development policy: Routledge. 